DOCUMENTO

\title{
“POLÍTICA E POLITICIDADE DA EDUCAÇÃO": uma disciplina sobre Paulo Freire lecionada em Portugal
}

Licínio C. Lima ${ }^{1}$

\section{Introdução}

O presente texto relata brevemente, e regista documentalmente, a construção e a experiência de lecionação de uma disciplina criada durante o ano letivo de 1998-1999 no então Departamento de Sociologia da Educação e Administração Educacional do Instituto de Educação e Psicologia da Universidade do Minho (Braga, Portugal), atualmente designado Departamento de Ciências Sociais da Educação do Instituto de Educação da UMinho.

A disciplina - agora sob a designação oficial de "unidade curricular", de acordo com as regras e terminologia inerentes ao chamado "Processo de Bolonha" -, foi aprovada por aquele Departamento e também pelo Conselho Científico do Instituto de Educação como unidade curricular do Curso de Mestrado em Ciências da Educação, com caráter opcional, integrando o plano de estudo de diversas áreas de especialização daquele Curso, funcionando no segundo semestre letivo do primeiro ano, durante quinze semanas e com a carga horária letiva de duas horas semanais (total de trinta horas presenciais ou de contacto).

\footnotetext{
1 Doutor em Educação. Professor Catedrático do Instituto de Educação da Universidade do Minho (Braga, Portugal). Autor de várias obras, sendo parte delas publicada no Brasil: Organização escolar e democracia radical - Paulo Freire e a governação democrática da escola pública; A Escola como Organização Educativa - Uma abordagem sociológica; Educação ao longo da vida. llima@ie.uminho.pt.
} 


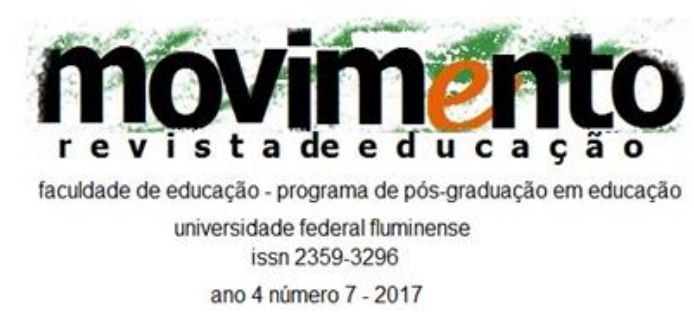

A disciplina foi intitulada "Política e Politicidade da Educação: o Pensamento de Paulo Freire", constituindo caso único, no contexto português, no que concerne à existência de uma disciplina curricular, oficialmente criada e em funcionamento regular, inteiramente dedicada ao estudo do pensamento e da obra de Paulo Freire.

A lecionação efetiva ocorreu pela primeira vez no ano letivo de 1999-2000, na área de especialização em Sociologia da Educação e Políticas Educativas, onde voltaria a ser lecionada no ano de 2002-2003. Até ao momento foi lecionada num total de oito vezes, também nas áreas de especialização em Administração Escolar (2000-2001), em Avaliação (2005-2006 e 2008-2009), e ainda em Educação de Adultos (2009-2010, 2010-2011 e 2014-2015).

O funcionamento desta disciplina tem sido condicionado pela abertura das referidas áreas de especialização do Curso de Mestrado em Ciências da Educação em cada ano letivo e, ainda, pela disponibilidade do docente que criou e que sempre lecionou a disciplina, tendo-se registado que, não obstante a sua natureza opcional, a disciplina, sempre que foi ofertada, foi efetivamente escolhida pelo número mínimo de estudantes exigidos, tendo sido efetivamente lecionada. Sobretudo a partir de meados da década compreendida entre os anos 2000 e 2010 verificou-se um significativo acréscimo de participantes, não apenas de mestrado, mas também de doutorado e até de colegas a realizar trabalhos de pós-doutorado, incluindo diversos estrangeiros, com destaque para participantes do Brasil, que nalgumas das edições chegaram a rondar os $50 \%$ do total de inscritos.

A circunstância de poder contar com estudantes e professores do Brasil enriqueceu consideravelmente a lecionação da disciplina, não apenas pelo conhecimento sobre Freire que alguns aportaram mas, especialmente, pelas suas contribuições para um mais profundo conhecimento da história, da 


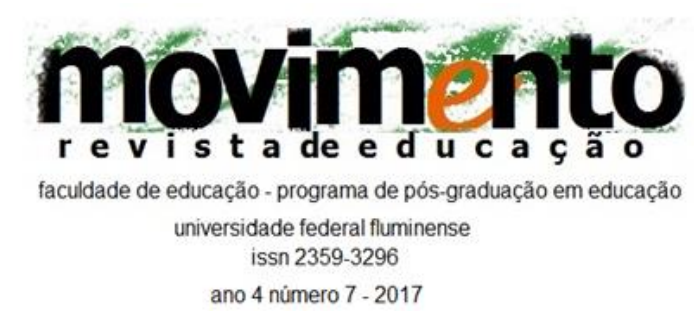

sociedade e da cultura brasileiras, elementos cruciais para contextualizar a vida e a obra de Freire, desde a sua infância no Bairro de Casa Amarela e, depois, em Jaboatão, até à sua formação em Direito, à sua ação no contexto dos movimentos católicos progressistas e do Movimento de Cultura Popular no Recife de Miguel Arraes, passando pelo trabalho de alfabetização realizado em Angicos e as responsabilidades assumidas nacionalmente durante o governo do presidente João Goulart, até ao golpe militar de 1964, a prisão e o exílio e, mais tarde, o seu regresso ao Brasil. Embora sustentado pelo docente e pelo recurso a fontes primárias e secundárias, o estudo do Brasil de Freire em muito tem beneficiado dos contributos de estudantes brasileiros, mesmo quando os mais jovens descobrem, ou aprofundam, em Portugal, acontecimentos históricos do seu país que lhes permitem uma melhor compreensão do homem e das suas circunstâncias, como escreveu o filósofo espanhol Ortega Y Gasset.

\section{Contexto institucional e percurso pessoal}

Tendo iniciado em 1975 projetos inovadores de formação inicial de professores, segundo o designado "modelo integrado" (ocorrência conjunta, desde o primeiro ano curricular de cada curso, da formação nas disciplinas da especialidade que o futuro docente viria a lecionar, a par da formação na componente de ciências da educação e na componente de prática pedagógica), a UMinho assumiu-se como um dos primeiros e mais importantes centros portugueses de ensino e de pesquisa em educação, sendo atualmente a maior escola do país neste domínio científico. Desde cedo, portanto, especialmente em disciplinas ligadas à filosofia da educação e ao estudo das correntes pedagógicas contemporâneas, mas também noutras áreas relacionadas com modelos e métodos de ensino, Paulo Freire viria a ser estudado e recomendado aos estudantes, sobretudo através das suas obras Educação como Prática da Liberdade e Pedagogia do Oprimido. Testemunhei isso mesmo como antigo aluno da UMinho, designadamente na 


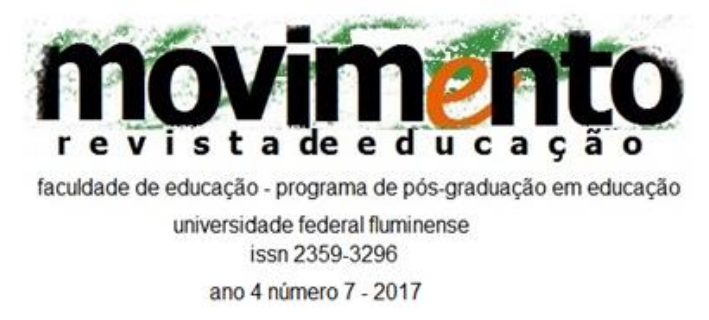

disciplina de Correntes Fundamentais da Pedagogia, lecionada pelo Prof. José Ribeiro Dias, onde, de resto, estudei também, em 1976-1977, Darcy Ribeiro e o seu Processo Civilizatório.

Embora publicada em Portugal em 1972, a Pedagogia do Oprimido era ainda, em meados da década, uma obra pouco conhecida, para especialistas ou ativistas pedagógicos, tal como o seu autor. A revolução democrática do 25 de abril de 1974 veio contribuir para alterar relativamente essa situação, especialmente no contexto da educação e alfabetização de adultos e através de receções diversas de Freire (ver Stoer e Dale, 1999).

Como recordei em entrevista concedida em 2005, em São Paulo, à Revista ecurriculum, editada pelo Programa de Pós-Gradução em Educação - Currículo, pela PUC-SP (Lima, 2006), onde por várias vezes participei em atividades desse Programa e da Cátedra Paulo Freire coordenada pela Prof ${ }^{a}$ Ana Maria Saul e pude trabalhar com vários professores como Antonio Chizzotti, Alípio Casali e outros, foi no final do meu curso de graduação que Paulo Freire surgiu de novo, nessa altura no contexto dos trabalhos de pesquisa em educação de adultos que iniciei em 1979 (na Unidade de Educação de Adultos da UMinho) pela mão de um grupo de especialistas suecos com quem trabalhei durante vários anos, em Portugal e na Suécia, conhecedores de Freire e que me instigaram a prosseguir novas leituras do autor. Tratava-se dos professores Thord Erasmie, Johan Norbeck (ambos da Universidade de Linköping) e de Harald Vallgårda (este reitor da Escola Superior Popular de Åsa, uma instituição típica da tradição nórdica de educação de adultos, expressa através do conceito de "Folkbildning").

Mais tarde, no início de década de 1990, já como responsável pelo Mestrado e pelo Doutorado em Organização e Administração Escolar do Instituto de Educação da UMinho e no contexto das minhas pesquisas sobre a gestão democrática das escolas, redescobri Paulo Freire através do livro A Educação 


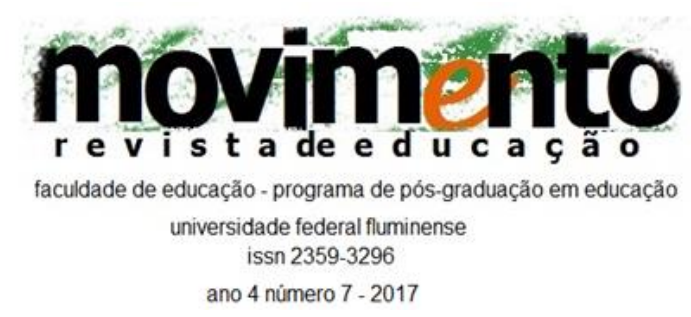

na Cidade, trazido ao meu conhecimento pelo meu colega Almerindo Afonso, na sequência de uma viagem sua ao Brasil. Foi a partir desse livro, então surpreendente para mim pelas novas temáticas trabalhadas por Freire e que particularmente me interessavam, no contexto da orientação de dissertações e teses em administração educacional e em sociologia da educação e políticas educativas na UMinho, que viria a proceder a uma leitura sistemática de toda a obra do autor, incluindo já todos os títulos que publicara após o seu regresso ao Brasil. Em 1997-1998 dediquei um ano sabático a esse estudo e à pesquisa das concepções de organização escolar e de democracia radical de Freire, tendo participado em vários eventos académicos e publicado, em 1998, o artigo intitulado "Mudando a Cara da Escola: Paulo Freire e a governação democrática da escola pública", inserido no número que a Revista Educação, Sociedade \& Culturas [Porto], n.ำ 10, dedicou a Paulo Freire (ver Lima, 1998). Na sequência da publicação desse e doutros trabalhos, viria a publicar no Brasil, em 2000, um ensaio intitulado Organização Escolar e Democracia Radical. Paulo Freire e a Governação Democrática da Escola Pública (Instituto Paulo Freire e Cortez Editora, atualmente em $5^{\circ}$ edição revista e ampliada), na sequência de interessantes debates com Moacir Gadotti e outros colegas, a que se seguiram outros textos apresentados e publicados em diversas línguas, em vários países (Brasil, Cuba, Espanha, Itália, México, Perú, Portugal).

A par de outras atividades de formação e intervenção socioeducativa realizadas em Cabo Verde, a partir do início da década de 1990, junto da Direção Geral de Educação Extra Escolar do Ministério da Educação, onde a obra de Paulo Freire representou importante referência, entendi estarem criadas as condições mínimas para propor, em 1998, a criação da disciplina opcional de mestrado intitulada "Política e Politicidade da Educação: o Pensamento de Paulo Freire", iniciando a sua lecionação no ano letivo de 1999-2000, após se ter dado início a um processo sistemático e continuado de aquisição de novas obras de Freire, em língua portuguesa e em língua inglesa, mais tarde complementado por 


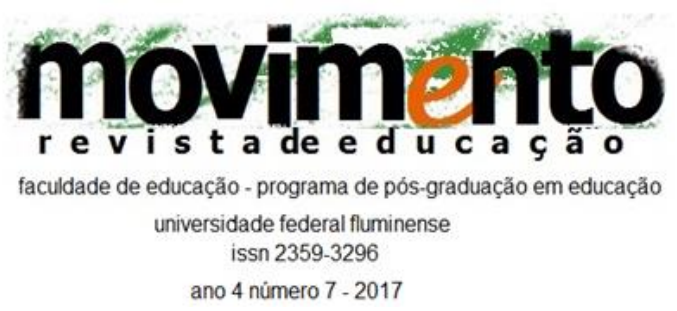

traduções noutras línguas, com destaque para o castelhano e o catalão, muitas destas na sequência da atividade editorial lavada a cabo pelo Instituto Paulo Freire de Espanha e a que fui tendo acesso através de várias iniciativas de colaboração, quase sempre a convite do seu presidente Pep Aparicio Guadas.

O programa da disciplina, cuja versão relativa à edição 2014-2015 se apresenta aqui (Apêndice I), mudou pouco em termos estruturais desde a primeira edição de 1999, talvez porque se tratasse, desde o início, de um programa aberto e passível de ser gerido de acordo com os interesses dos estudantes. O que foi sendo alterado prendeu-se mais com os textos referidos na bibliografia, incorporando trabalhos de relevo entretanto publicados e, ainda, reunindo um maior acervo de documentos e materiais didáticos disponíveis. Em ambos os casos procurando evitar longas listas de referências bibliográficas e de outro tipo de recursos, antes os convocando para as sessões letivas e de acordo com os interesses revelados pelos estudantes.

As experiências de estudo, de escrita e de lecionação que foram sendo desenvolvidas permitiram a realização de outras atividades que contribuíram para a formação do docente da disciplina, para o contacto com especialistas estrangeiros e a participação em importantes reuniões científicas e educativas. Entre outras, merecem destaque: a criação, em 2001, através de escritura notarial, do Instituto Paulo Freire de Portugal (ato formal que contou com as assinaturas de Steve Stoer, Luiza Cortesão, António Teodoro, Licínio Lima); várias participações nos seminários internacionais promovidos pelo Centro Paulo Freire de Estudos e Pesquisa, do Recife, a convite de Paulo Rosas e, mais tarde, de João Francisco de Souza e demais colegas da direção daquele Centro; o trabalho de seminário, mais tarde publicado em forma de livro, realizado a convite de Carlos Nuñez Hurtado, da Cátedra Paulo Freire do ITESO, em 2002, em Guadalajara (México), que juntou ainda Ana Saul e Alípio Casali; a conferência inaugural do IV Encontro Internacional do Fórum Paulo Freire, 


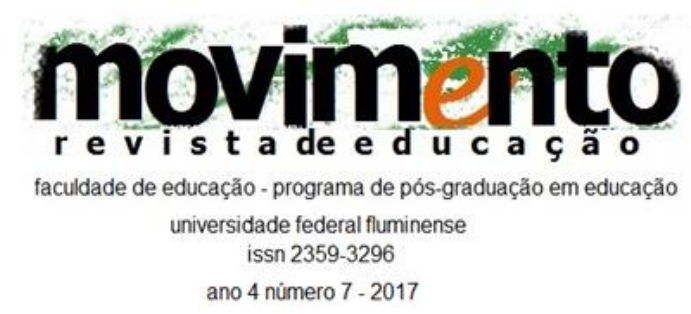

realizado no Porto em 2004, onde pude contar com os comentários de Carlos Alberto Torres e João Teixeira Lopes; a direção e lecionação, em julho de 2006, do I Curso de Verão - Oficina de Saberes, promovido pelo Departamento de Sociologia da Educação e Administração Educacional da UMinho, sob o tema "Paulo Freire e a Educação na Cidade", tendo contado com uma conferência de abertura de Luiza Cortesão; a direção científica do Simpósio Paulo Freire, Vida e Obra, organizado pela Direção Regional da Educação da Madeira em 2010, onde apresentei a obra de Ana Maria Araújo Freire (2006) intitulada Paulo Freire, Uma História de Vida; o ciclo de conferências que proferi a convite da Prefeitura do Recife em 2011, por ocasião das comemorações dos 90 anos do nascimento de Freire; as numerosas palestras e conferências proferidas sobre a obra freiriana, na PUC-SP, no Instituto Federal do Rio Grande do Norte (2013), na Universidade do Estado do Pará (2014), entre tantas outras, tendo a mais recente ocorrido em Itália, na Universidade de Verona, em junho de 2017.

A par das contribuições e do interesse revelado por outros colegas, e também por estudantes de gradução e de pós-graduação, do Instituto de Educação da UMinho, esta instituição viria a decidir, através do seu Conselho Científico, atribuir o nome de Paulo Freire à Sala daquele Conselho, tendo por base uma Informação (ver Apêndice II) que redigi em setembro de 2014, a solicitação do Presidente do Instituto, Prof. José Augusto Pacheco. A cerimónia formal de atribuição do nome de Paulo Freire à Sala de Reuniões do Conselho Científico do Instituto de Educação da UMinho ocorreu a 12 de dezembro de 2016, com descerramento da sua fotografia, uma exposição bibliográfica, o visionamento da última entrevista que concedeu e uma conferência, seguida de debate, que proferi, subordinada ao título "Quatro razões para ler Freire, para além da mais óbvia" (ver Convite em Apêndice III). 


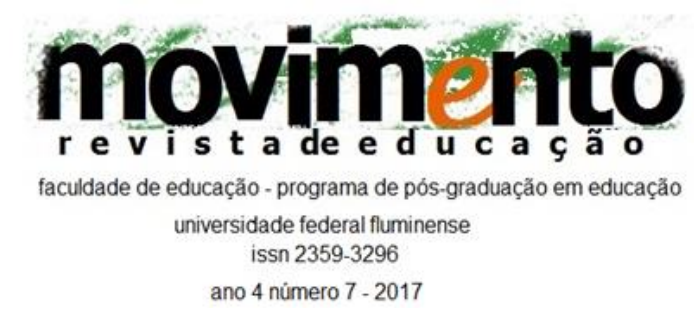

\section{Sobre a experiência de lecionação}

A disciplina foi construída a partir de um enfoque de política educacional, convocando olhares cruzados da sociologia da educação e dos estudos organizacionais sobre as escolas e outras instâncias educativas não escolares, desta feita abrindo-se a diferentes áreas de especialização do Curso de Mestrado e a uma gestão pedagógica aberta, dotada da necessária plasticidade para se adequar aos respetivos perfis de formação e aos interesses estudantis. Funcionando em regime de seminário é grande a liberdade de docente e discentes, tanto mais quanto os conteúdos programáticos encerram mais a natureza de uma proposta metodológica do que propriamente o caráter de lista fixa, ou imutável, de conteúdos a serem abordados. Mesmo quando, com frequência, acabam por ser todos abordados, embora com distintas centralidades e variáveis graus de aprofundamento.

Os resultados de aprendizagem pretendidos com a lecionação da disciplina incluem: 1) Reconhecer os princípios estruturantes e os conceitos básicos da obra de Paulo Freire; 2) Identificar as principais fases do pensamento de Freire, de acordo com o seu contexto histórico e cultural; 3) Relacionar as contribuições freirianas com a pedagogia crítica e com a democracia radical; 4) Aplicar os conceitos freirianos ao estudo da escola como organização educativa e à educação popular e de adultos; 5) Analisar os conceitos de participação, descentralização e autonomia.

Os conteúdos da disciplina encontram-se organizados em três módulos. Num primeiro momento, de introdução, são apresentadas as fases da vida e da obra do autor, os contextos histórico e político da sua atividade, dentro e fora do Brasil, algumas das ideias, os movimentos e os autores que mais influenciaram a sua obra, designadamente através do recurso a fontes primárias e secundárias. Um segundo módulo dedica-se a apresentar elementos centrais do pensamento 


\section{movimento \\ faculdade de educação - programa de pós-graduação em educação universidade federal fluminense \\ issn 2359-3296 \\ ano 4 número 7 - 2017}

freiriano, de acordo com a abordagem de uma sociologia política e organizacional da educação, escolar e não escolar, que foi aquela que foi selecionada para orientar a construção científica e pedagógica da disciplina. Aqui são introduzidas problemáticas selecionadas de acordo com aquela orientação, conceitos e categorias centrais na obra de Freire, trabalho que é realizado pelo docente e pelos estudantes a partir da análise das suas obras e do estudo de outros autores, procurando constituir uma gramática conceitual freiriana que apoie o trabalho posterior dos estudantes, ao longo do módulo terceiro. Neste último, os estudantes, geralmente organizados em grupos de trabalho constituídos por dois elementos, procedem à apresentação oral e escrita, seguida de debate, de uma obra previamente selecionada com a participação do docente e dos demais estudantes. Para o efeito é apresentada uma lista de obras, sugerida pelo docente no programa da disciplina, organizada cronologicamente, da mais recente para a mais antiga em termos de data de publicação, embora outras obras possam ser incluídas por proposta dos estudantes. Cada grupo, para além da análise crítica de uma obra, é solicitado a estabelecer relações com outras obras de Freire e, necessariamente, com outras fontes secundárias consideradas pertinentes. Cada apresentação ocorre numa aula específica para esse efeito, até ao limite de uma hora, sendo a segunda hora dedicada à discussão do trabalho apresentado.

A experiência de lecionação desta disciplina permite reconhecer o elevado interesse que a obra de Freire é capaz de despertar nos estudantes de pósgraduação, os quais, na sua maioria, conhecem apenas o nome do autor, um ou outro conceito ou título de livro, ou ideia geralmente cristalizada, transformada em lugar-comum. Ultrapassada a fase inicial de receio quanto ao possível caráter fastidioso de uma disciplina inteiramente dedicada a um autor, algo cada vez menos frequente na experiência atual dos universitários e que, de resto, não deixou de ser referido em tom de advertência aquando da aprovação da disciplina pelos órgãos responsáveis, os estudantes entregam-se, 


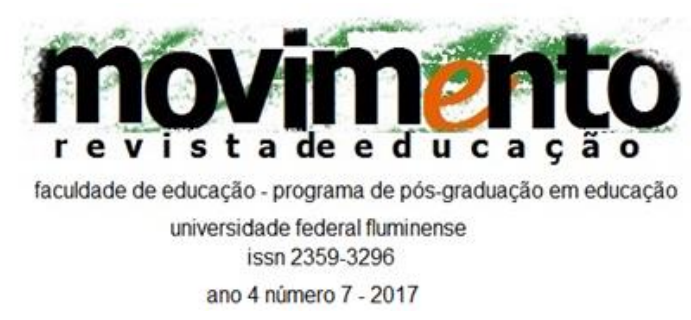

invariavelmente, à tarefa de estudar Freire, de pesquisar fontes, documentos e testemunhos vários, realizando apresentações geralmente de grande qualidade e, nalguns casos mesmo de profundidade assinalável. Contudo, é a criatividade colocada nas apresentações dos trabalhos dos grupos que mais se tem destacado (filmes, cartas, entrevistas imaginárias a Freire e respetivas respostas, entre outros recursos).

Com efeito, mesmo admitindo graus de adesão muito variáveis às ideias propostas por Freire, os estudantes revelam o seu espírito crítico e indagador, por vezes desafiando-as e opondo-Ihes teses e perspectivas em tensão, partindo de distintos referenciais teóricos ou adotando diferentes quadros axiológicos e ético-políticos. Mas isso releva já da sua elevada motivação para o estudo crítico de Freire e de uma certa atração que o autor parece continuar a exercer, ora pelas suas ideias e pela criatividade da sua linguagem, ora pela sofisticação de alguns dos seus argumentos, em qualquer dos casos evidenciando capacidade para motivar estudos e debates. Isso é, também, notado por alguns docentes de outras disciplinas do mesmo curso; existe, dizem, um antes e um depois de os estudantes se confrontarem com Freire ou, como um desses colegas sempre refere, emerge nos estudantes uma espécie de efeito de "contaminação" que se faz sentir noutras disciplinas, nos conceitos convocados, no recurso às obras do autor.

Num momento em que a formação universitária de professores e educadores parece perder fulgor teórico e intelectual, valorizar pouco a cultura, a erudição e a história das ideias educacionais, tender para a naturalização dos discursos hegemónicos em torno da performatividade competitiva, das "melhores práticas", das qualificações e das competências de tipo vocacional, assim despolitizando a educação e a formação, talvez o retorno ao estudo dos autores críticos, como é o caso, entre muitos outros, de Paulo Freire, represente uma opção relevante e uma contribuição para resgatar Freire; seja de abordagens fixistas e limitadas 


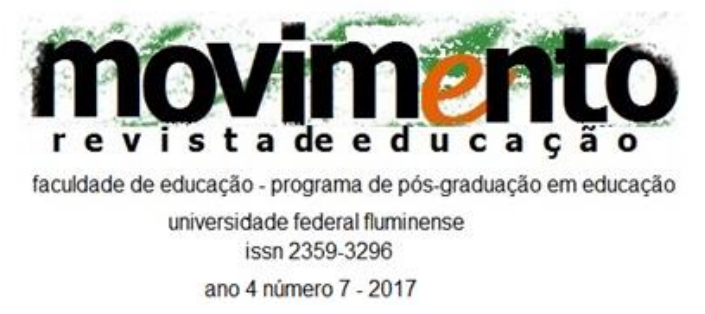

à reprodução mais ou menos seguidista de um pequeno corpus de ideias ou citações, atomizadas, por parte de setores que se afirmam seus defensores, seja, também, da ignorância e da desonestidade intelectual que transparece das críticas feitas pelos seus detratores em termos puramente ideológicos, como tem sucedido com particular violência discursiva no Brasil. Estudar, estudar seriamente e criticamente a obra do autor, constitui para nós uma exigência universitária indeclinável. 


\title{
movimento \\ r e v i s t a de e d u c a ç ã o \\ faculdade de educação - programa de pós-graduação em educação \\ universidade federal fluminense \\ issn 2359-3296 \\ ano 4 número 7 - 2017
}

Apêndice I - Programa da disciplina relativo ao ano letivo 2014/2015

\author{
CURSO DE MESTRADO EM CIÊNCIAS DA EDUCAÇÃO \\ ÁREA DE ESPECIALIZAÇÃO EM EDUCAÇÃO DE ADULTOS
}

2014/2015

(11ª Edição)

\section{POLÍTICA E POLITICIDADE DA EDUCAÇÃO: O PENSAMENTO DE PAULO FREIRE}

\author{
Unidade Curricular de Opção \\ (II Semestre, 2h/semana)
}

Docente

Licínio C. Lima

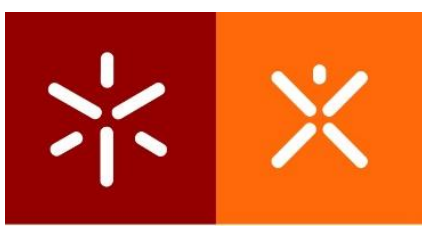

UNIVERSIDADE DO MINHO

INSTITUTO DE EDUCAÇÃO

\section{Apresentação}

Política e Politicidade da Educação elege como referência central o pensamento de Paulo Freire, tomando congruentemente como base de trabalho privilegiado as obras deste autor e também outros trabalhos de crítica e exegese do pensamento freiriano.

Para Paulo Freire, educação e política, pedagogia e ideologia, são consideradas inseparáveis, logo a partir dos mais elementares traços constitutivos do processo pedagógico, com destaque para a seleção (não 


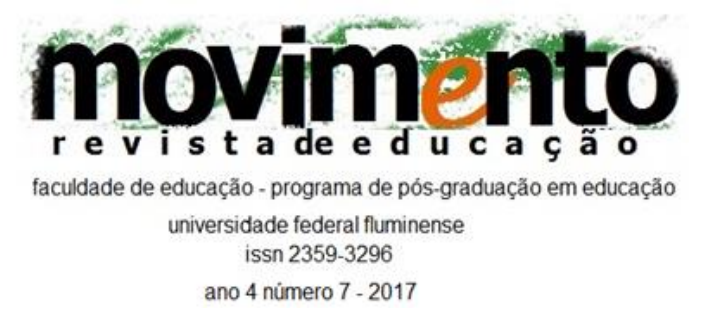

natural) dos conteúdos e para a escolha (arbitrária) dos objetivos do ensino. Para Freire é a necessária existência de objetivos que confere à educação o seu caráter diretivo, que a torna "uma forma de intervenção no mundo", seja para a reprodução seja para a transformação, e daí, também, releva a impossibilidade da sua neutralidade e apoliticidade.

Pelo contrário, a neutralidade da educação é associável a visões despolitizadas e ingénuas, a representações descontextualizadas e fragmentárias de ação pedagógica, a perspectivas ideológicas capazes de ocultarem ou naturalizarem o caráter ideológico das suas opções e interesses. Ao considerar que a educação é, pela sua natureza, uma atividade política, Paulo Freire não atribui apenas uma dimensão política a todas as atividades educativas, não se limita a identificar um elemento político no processo de ensino-aprendizagem, nem a conferir conotação política genérica à ação pedagógica. Para o autor, educação é política. $\mathrm{E}$ por isso não existe o estritamente pedagógico, o exclusivamente administrativo, o singularmente didático.

Ficam, assim, superadas as focalizações de tipo atomizante, seja considerando educação e política enquanto meras variáveis, ou como esferas independentes que por vezes se cruzam ou atraem, ou como subsistemas em interação, e também outras perspectivas deterministas e de sistema social que ora subordinam o educativo ao político, ora reduzem mesmo o primeiro a um reflexo do segundo.

Neste quadro de relações e de possibilidades em aberto, saber interpretar e analisar criticamente as políticas para a educação, as políticas educativas e pedagógicas, e também as ações educativas e as práticas pedagógicas enquanto ações políticas, parece indispensável e constitui objetivo central desta unidade curricular.

\section{Resultados de Aprendizagem:}

1. Reconhecer os princípios estruturantes e os conceitos básicos da obra de Paulo Freire;

2. Identificar as principais fases do pensamento de Freire, de acordo com o seu contexto histórico e cultural;

3. Relacionar as contribuições Freirianas com a pedagogia crítica e com a democracia radical; 


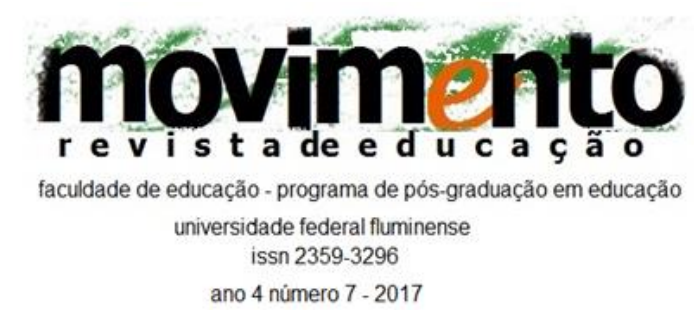

4. Aplicar os conceitos Freirianos ao estudo da escola como organização educativa e à educação popular e de adultos;

5. Analisar os conceitos de participação, descentralização e autonomia.

\section{Programa}

\section{I - Introdução}

1. Paulo Reglus Neves Freire (1921-1997).

2. Do Serviço Social da Indústria (1947) à intervenção nacional no governo João Goulart: Educação e Atualidade Brasileira (1959), Cultura e participação no Recife: o método de alfabetização.

3. O exílio (1964-1980): A Educação como Prática da Liberdade (1967), Acção Cultural para a Liberdade e Outros Escritos (1968), Pedagogia do Oprimido (1970).

d) O "renascimento pedagógico" e a intervenção político-educativa de regresso ao Brasil (1980-1997): A Educação na Cidade (1991) a Pedagogia da Autonomia (1996) e a Pedagogia da Indignação (2000).

e) Biobliografia (M. Gadotti et al., 1996; A. M. Freire, 2006): outras biografias, depoimentos e testemunhos; a obra de Paulo Freire; escritos, teses e investigações sobre Paulo Freire. O legado, os Institutos e as Cátedras Paulo Freire. Outras fontes.

\section{II - O Pensamento de Paulo Freire}

6. Educação como prática da liberdade: a participação livre e crítica dos educandos, pedagogia democrática, educação para e pela democracia, práticas dialógicas; consciência ingénua, consciência crítica e conscientização; teoria da participação democrática radical.

7. Educação para a libertação e a emancipação; as críticas ao extensionismo, à invasão cultural, ao slogan, à conquista e ao dirigismo 


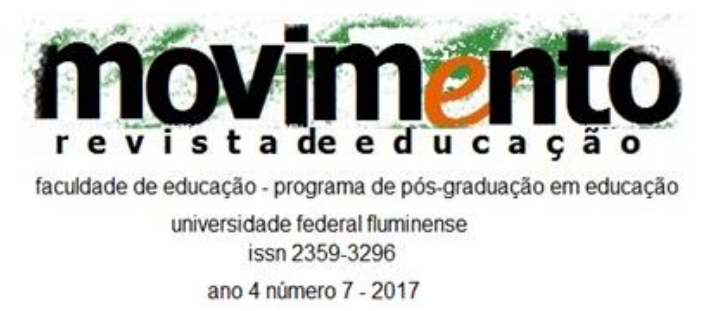

e vanguardismo;

domesticação/libertação;

modernização/desenvolvimento.

8. Democracia radical e cidadania crítica; educação bancária e educação problematizadora; mobilização organizacional e organização verdadeira; participação como ingerência; leitura do mundo e leitura da palavra; a descodificação e a prática de pensar as práticas; pedagogia do oprimido.

9. Politicidade da educação e educabilidade e natureza pedagógica da ação política; política educativa e educação política; a diretividade da educação; a educação como intervenção no mundo para a reprodução e para a transformação; a relação dialética prática-teoria; os sujeitos em formação; a pesquisa participante, sujeitos e objetos da investigação na produção do conhecimento.

10.Organização escolar, democracia radical e governação da escola pública; a educação na cidade e a mudança da cara da escola; participação comunitária, participação dos pais e cidadania crítica; descentralização, participação, autonomia, municipalização; os conselhos de escola e outros coletivos escolares; a pedagogia da autonomia e a autonomia da pedagogia; a democratização dos poderes educativos.

\section{III - Análise Crítica e Discussão de Algumas Obras de Paulo Freire: Apresentações realizadas por grupos de trabalho (a selecionar)}

11. Pedagogia da Autonomia: Saberes Necessários à Prática Educativa (1996)

12. Cartas a Cristina (1994)

13. Professora Sim, Tia Não. Cartas a Quem Ousa Ensinar (1993)

14. Pedagogia da Esperança. Um Reencontro com a Pedagogia do Oprimido (1992)

15. A Educação na Cidade (1991)

16. A Importância do Ato de Ler em Três Artigos que se Completam (1982)

17. Cartas à Guiné-Bissau. Registros de uma Experiência em Processo (1978)

18. Pedagogia do Oprimido (1970)

19. Extensão ou Comunicação? (1969) 


\section{movimento \\ faculdade de educação - programa de pós-graduação em educação universidade federal fluminense issn 2359-3296 \\ ano 4 número 7 - 2017}

20. Educação como Prática da Liberdade (1967)

21. Educação e Actualidade Brasileira (1959).

\section{Organização das sessões}

As sessões de trabalho serão organizadas de forma a contemplar a intervenção ativa dos participantes no curso. As primeiras sessões ficarão a cargo do docente, sendo as restantes sessões (relativas ao ponto III do Programa) utilizadas para a apresentação e discussão dos trabalhos elaborados pelos grupos e avaliação final.

Serão formados vários grupos de trabalho (cada um reunindo 2 participantes) e cada grupo será responsável pela apresentação oral e escrita de um trabalho de análise crítica que incidirá sobre uma obra de Paulo Freire (a indicar pelo docente) e que contemplará obrigatoriamente outras obras, de outros autores, que incidem sobre o pensamento de Freire. Cada grupo disporá de uma sessão letiva durante a qual apresentará o seu trabalho (até ao limite de 1 hora) e o discutirá (durante a segunda hora) com os colegas e o docente, seguindo-se uma síntese final.

\section{Avaliação}

A avaliação da presente unidade curricular resultará das seguintes componentes, com os correspondentes fatores de ponderação:

1. Nível de participação de cada estudante ao longo de pelo menos dois terços das sessões letivas efetivamente ministradas (peso 1);

2. Elaboração, apresentação individual e defesa de parte, ou seção, de um trabalho realizado em grupo, podendo haver lugar à atribuição de classificações distintas no interior do mesmo grupo, considerando os desempenhos individuais (peso 2);

Os estudantes que, ao abrigo da legislação em vigor, tenham obtido 0 estatuto de trabalhador-estudante e não participem em pelo menos dois terços das sessões letivas previstas no número 1 verão essa componente de avaliação ser substituída pela análise de uma obra a indicar, dando lugar à redação de um relatório crítico, com base em regras previamente fornecidas, o qual será objeto de discussão oral com o docente. 


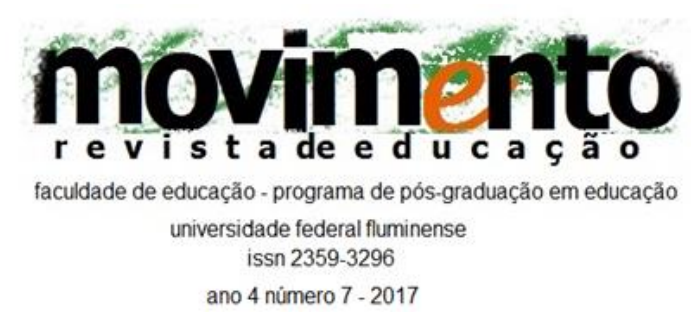

Para o efeito, os trabalhadores-estudantes nessas circunstâncias informarão o docente do seu estatuto, até 15 dias após o início das aulas, sendo-Ihe então comunicadas a obra a analisar e respetivas regras de apresentação do relatório crítico.

\section{Bibliografia}

ALLMAN, Paula (1994). "Paulo Freire's Contributions to Radical Adult Education", Studies in the Education of Adults, Vol. 26, № 2, 144-161.

APPLE, Michael W. (1998). "Freire, Neoliberalismo e Educação", in M. W. Apple \& A. Nóvoa (orgs.), Paulo Freire: Política e Pedagogia. Porto: Porto Editora, 21-45.

ARANOWITZ, Stanley (1993). "Paulo Freire's Radical Democratic Humanism", in P. McLaren \& P. Leonard (eds.), Paulo Freire: A Critical Encounter. Londres: Routledge, 8-24.

AAVV (2000). Paulo Freire Entre Nosotros. La Habana/Guadalajara: CIE/IMDEC.

BEISIEGEL, Celso de Rui (1992). Política e Educação Popular. A Teoria e a Prática de Paulo Freire no Brasil. São Paulo: Ática ( $3^{\underline{a}}$ ed.).

BRANDÃO, Carlos Rodrigues (2005). Paulo Freire, o Menino que Lia o Mundo. São Paulo: Editora UNESP.

CAMARGO, Elizabete (1997). "Editorial. Paulo Freire (19.9.1921/2.5.1997)", Educação \& Sociedade, Ano XVIII, № 60, 7-11.

CAMPOS, Fátima (1998). "Paulo Freire: actualidade e urgência da sua práxis e do seu discurso", Revista de Educação, III, no 1, 9-26.

CASALI, Alípio (1998). "Paulo Freire: o educador na história", Educação, Sociedade \& Culturas, № 10, 95-109.

CASALI, Alípio, LIMA, Licínio C., NUÑEZ, Carlos \& SAUL, Ana Maria (2005). Propuestas de Paulo Freire para una Renovación Educativa. Tlaquepaque (México): ITESO/CREFAL/CEAAL.

CARVALHO, Maria João de (2009). Paulo Freire: a construção da escola democrática a partir da decisão. Revista Brasileira de Política e Administração da Educação, Vol. 25, № 3, pp. 441-454. 


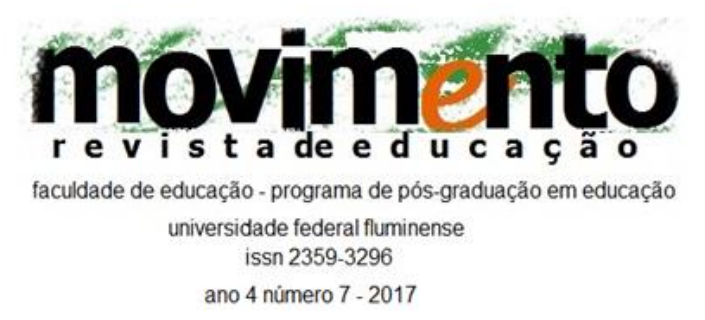

CENTRO PAULO FREIRE - ESTUDOS E PESQUISAS (2000). Um Olhar sobre Paulo Freire a Partir da Realidade Cultural do Nordeste Brasileiro. Recife: Edições Bagaço/NUPEP.

COBERN, Diana (2001). Gramsci y Freire, Héroes Radícales. Politicas en Educación de Adultos. Buenos Aires/Madrid: Fundación Paideia/Miño y Dávila.

COOPER, Gillian (1995). "Freire and Theology", Studies in the Education of Adults, Vol. 27, no 1, 66-78.

CORTESÃO, Luisa et al. (2002). Um Caderno Novo. Porto: Instituto Paulo Freire de Portugal.

FREIRE, Ana Maria Araújo (2006). Paulo Freire. Uma História de Vida. Indaiatuba: Villa das Letras.

FREIRE, Ana Maria Araújo (Org.) (2001). A Pedagogia da Libertação em Paulo Freire. São Paulo: Editora UNESP.

FREIRE, Paulo (1961). A Propósito de uma Administração. Recife: Imprensa Universitária.

FREIRE, Paulo (1967). Educação como Prática da Liberdade. Rio de Janeiro: Paz e Terra.

FREIRE, Paulo (1975a). Extensão ou Comunicação? Rio de Janeiro: Paz e Terra (1ㄹ ed. de 1969).

FREIRE, Paulo (1975b). Pedagogia do Oprimido. Porto: Afrontamento.

FREIRE, Paulo (1976). Ação Cultural para a Liberdade e Outros Escritos. Rio de Janeiro: Paz e Terra (1 $\stackrel{\underline{a}}{\text { ed. de }}$ 1975).

FREIRE, Paulo (1978). Cartas à Guiné-Bissau. Registros de uma Experiência em Processo. Rio de Janeiro: Paz e Terra (4⿳亠丷a ed.).

FREIRE, Paulo (1980). Conscientização. Teoria e Prática da Libertação. Uma Introdução ao Pensamento de Paulo Freire. São Paulo: Moraes.

FREIRE, Paulo (1981). "Criando métodos de pesquisa alternativa: aprendendo a fazê-la melhor através da ação", in C. Rodrigues Brandão (org.), Pesquisa Participante. São Paulo: Brasiliense, 34-41.

FREIRE, Paulo (1985). The Politics of Education, Culture, Power, and Liberation. Nova York: Bergin \& Garvey. 


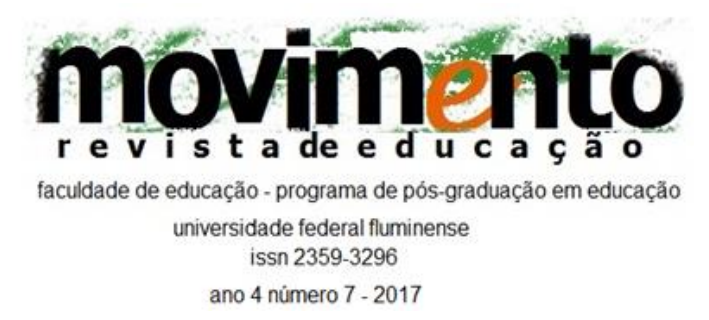

FREIRE, Paulo (1988). Educação e Mudança. São Paulo: Paz e Terra (1ª ed. de 1979).

FREIRE, Paulo (1991). A Educação na Cidade. São Paulo: Cortez Editora.

FREIRE, Paulo (1993). "Foreword", in P. McLaren \& P. Leonard (eds.), Paulo Freire: A Critical Encounter. Londres: Routledge, ix-xii.

FREIRE, Paulo (1994a). Cartas a Cristina. Rio de Janeiro: Paz e Terra.

FREIRE, Paulo (1994b). In Paulo Freire \& Frei Betto, Essa Escola Chamada Vida. Depoimentos ao Repórter Ricardo Kotscho. São Paulo: Ática (1르 ed. de 1985).

FREIRE, Paulo (1994c). in M. Escobar, A.L. Fernández, G. Guevara-Niebla with P. Freire. Paulo Freire on Higher Education. A Dialogue at the National University of Mexico. Albany: Suny Press.

FREIRE, Paulo (1996a). "Educação e Participação Comunitária", Inovação, no 9, 305-312.

FREIRE, Paulo (1996b). Pedagogia da Autonomia. Saberes Necessários à Prática Educativa. São Paulo: Paz e Terra.

FREIRE, Paulo (1997a). Pedagogia da Esperança. Um Reencontro com a Pedagogia do Oprimido. São Paulo: Paz e Terra (1르 ed. de 1992).

FREIRE, Paulo (1997b). A Importância do Ato de Ler, em Três Artigos que se Completam. São Paulo: Cortez Editora (1 ${ }^{\underline{a}}$ ed. de 1982).

FREIRE, Paulo (1997c). Professora Sim, Tia Não. Cartas a Quem Ousa Ensinar. São Paulo: Olho d'Água ( $1^{\mathrm{a}}$ ed. de 1993).

FREIRE, Paulo (1997d). "Nós somos seres da briga", Público de 4 de Maio de 1997, 36-37 (entrevista concedida a João Pedro Serafim).

FREIRE, Paulo (2000a). À Sombra desta Mangueira. São Paulo: Olho d' Água (3르. ed.).

FREIRE, Paulo (2000b). Pedagogia da Indignação. Cartas Pedagógicas e Outros Escritos. São Paulo: Editora UNESP (1 ${ }^{\underline{a}}$ ed.).

FREIRE, Paulo (2001). Educação e Atualidade Brasileira. São Paulo: Cortez/Instituto Paulo Freire ( $1^{\underline{a}}$ ed.).

FREIRE, Paulo (2004). Pedagogia da Tolerância. São Paulo: Editora UNESP. 


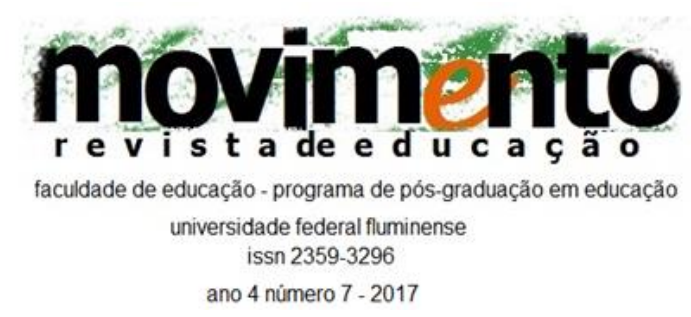

FREIRE, Paulo \& FAUNDEZ, Antonio (1998). Por uma Pedagogia da Pergunta. Rio de Janeiro: Paz e Terra ( $4^{\underline{a}}$ ed.).

FREIRE, Paulo \& GIROUX, Henry A. (1989). "Pedagogy, Popular Culture, and Public Life: an introduction", in Henry A. Giroux, Roger I. Simon \& Contributors, Popular Culture, Schooling, and Everyday Life. Nova York: Bergin \& Garvey, vii-xii.

FREIRE, Paulo \& GUIMARÃES, Sérgio (1987). Aprendendo com a Própria História, Vol. I. Rio de Janeiro: Paz e Terra (1를. ed.).

FREIRE, Paulo \& MACEDO, Donaldo (1990). Alfabetização. Leitura do Mundo, Leitura da Palavra. São Paulo: Paz e Terra (1 $1^{\text {a }}$ ed. de 1987).

FREIRE, Paulo \& MACEDO, Donaldo (1993). "A dialogue with Paulo Freire", in P. McLaren \& P. Leonard (eds.), Paulo Freire: A Critical Encounter. Londres: Routledge, 169-176.

FREIRE, Paulo \& SHOR, Ira (2000). Medo e Ousadia. O Cotidiano do Professor. Rio de Janeiro: Paz e Terra ( $8^{\underline{a}}$ ed.).

GADOTTI, Moacir (1988). "Prefácio. Educação e Ordem Classista", in Paulo Freire, Educação e Mudança. São Paulo: Paz e Terra (1ª ed. de 1979), 914.

GADOTTI, Moacir (1998). "Lições de Freire", Educação, Sociedade \& Culturas, № 10, 111-122.

GADOTTI, Moacir (2001). Convite à Leitura de Paulo Freire. São Paulo: Scipione.

GADOTTI, Moacir (2001). "Cruzando fronteiras. Teoria, métodos e experiências Freireanas", in A. Teodoro (Org.), Educar, Promover, Emancipar. Lisboa: Edições Universitárias Lusófonas, pp. 47-77.

GADOTTI, Moacir et al. (1996). Paulo Freire: Uma Biobliografia. São Paulo: Cortez Editora.

GADOTTI, Moacir, FREIRE, Paulo \& GUIMARÃES, Sérgio (1995). Pedagogia: Diálogo e Conflito. São Paulo: Cortez ( $4^{\mathrm{a}} \mathrm{ed}$.).

GADOTTI, Moacir \& TORRES, Carlos Alberto (1991). "Paulo Freire, Administrador Público", in Paulo Freire, A Educação na Cidade. São Paulo: Cortez Editora, 11-17. 


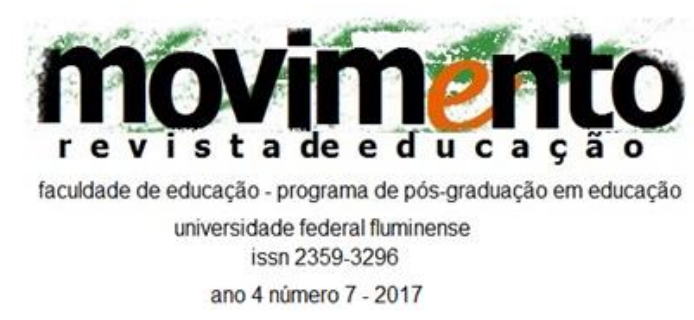

GIBSON, Alan (1994). "Freirean versus entreprise education: the difference is in the business", Convergence, Vol. XXVII, № 1, 46-57.

GIROUX, Henry (1983). Pedagogia Radical. Subsídios. São Paulo: Autores Associados/ Cortez.

GIROUX, Henry A. (1997). "Paulo Freire e a Política de Pós-Colonialismo", Pátio, Ano I, no 2, 15-19.

hooks, bell (1993). "bell hooks speaking about Paulo Freire: the man, his work", in P. McLaren \& P. Leonard (eds.), Paulo Freire: A Critical Encounter. Londres: Routledge, 146-154.

JARDILINO, José Rubens L. (2000). Paulo Freire. Retalhos Biobibliográficos. São Paulo: Edições Pulsar.

JARVIS, Peter (1987). "Paulo Freire: Educationalist of a Revolutionary Christian Movement", Convergence, Vol. XX, № 2, 30-41.

JARVIS, Peter (1991). "Paulo Freire", in P. Jarvis (ed.), Twentieth Century Thinkers in Adult Education. Londres: Routledge, 265-279.

LIMA, Licínio C. (1998). "Mudando a Cara da Escola: Paulo Freire e a governação democrática da escola pública", Educação, Sociedade \& Culturas [Porto], n.ำ 10, pp. 7-55.

LIMA, Licínio C. (2000). Organização Escolar e Democracia Radical. Paulo Freire e a Governação Democrática da Escola Pública. São Paulo: Cortez Editora/Instituto Paulo Freire.

LIMA, Licínio C. (2002). "A Democratização das Organizações Educativas e a Participação como Ingerência: Contribuição de Paulo Freire", Forum, n.o 31, pp. 81-94.

LIMA, Licínio C. (2005). "Cidadania e Educação: adaptação ao mercado competitivo ou participação na democratização da democracia. Educação, Sociedade \& Culturas, no 23, pp. 71-90.

LIMA, Licínio C. (2005). "Escolarizando para uma Educação Critica: a reinvenção das escolas como organizações democráticas", in António Teodoro \& Carlos Alberto Torres (Orgs.), Educação Critica e Utopia. Perspectivas para o Século XXI. Porto: Afrontamento, pp. 19-31.

LIMA, Licínio C. (2006). "Estudar Paulo Freire", entrevista concedida à Revista e-curriculum da Pontifícia Universidade Católica de São Paulo [Brasil], vol. 1, n.․ 2, Junho de 2006, 13 pp. (http://www.pucsp.br/curriculum). 


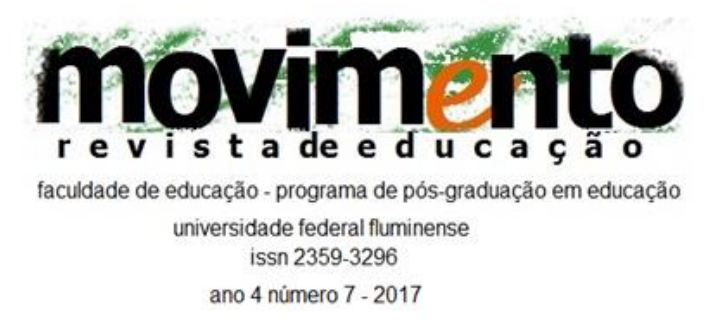

LIMA, Licínio C. (2007). Educação ao Longo da Vida. Entre a Mão Direita e a Mão Esquerda de Miró. São Paulo: Cortez Editora.

LIMA. Licínio C. (2007). "Crítica da Educação Indecisa: a propósito da Pedagogia da Autonomia de Paulo Freire", in Revista e-curriculum [São Paulo/Brasil], Vol. 7, no 3, pp. 1-12.

LINHARES, Célia \& TRINDADE, Maria Nazaret (Orgs.) (2003). Compartilhando o Mundo com Paulo Freire. São Paulo: Cortez Editora/Instituto Paulo Freire.

LUCIO-VILLEGAS RAMOS, Emílio Luís \& APARICIO GUADAS, Pep (2004). Educación, Democracia y Emancipación. Barcelona: Diálogos.

MACEDO, Donaldo (1994). Literacies of Power. What Americans Are Not Allowed to Know. Boulder: Westview Press.

MACEDO, Eunice et al. (2001). Revisitando Paulo Freire. Sentidos na Educação. Porto: Asa.

MAYO, Peter (1993). "When Does it Work? Freire's Pedagogy in Context", Studies in the Education of Adults, Vol. 25, no 1, 11-30.

MAYO, Peter (1999). Gramsci, Freire and Adult Education. Possibilities for Transformative Action. Londres: Zed Books.

McLAREN, Peter (1994). "Foreword", in M. Escobar, A.L. Fernández, G. Guevara-Niebla with P. Freire. Paulo Freire on Higher Education. A Dialogue at the National University of Mexico. Albany: Suny Press, ixxxxiii.

McLAREN, Peter (1997). "Um Legado de Luta e de Esperança”, Pátio, Ano I, no $2,10-13$

McLAREN, Peter (1998). "A Pedagogia da Possibilidade de Paulo Freire", Educação, Sociedade \& Culturas, ํㅜ 10, 57-82.

McLAREN, Peter \& SILVA, Tomaz Tadeu da (1993). "Decentering Pedagogy. Critical Literacy, Resistance and the Politics of Memory", in P. McLaren \& P. Leonard (eds.), Paulo Freire: A Critical Encounter. Londres: Routledge, 47-89.

MONCLÚS, António (1988). Pedagogía de la Contradicción: Paulo Freire. Barcelona: Anthropos. 


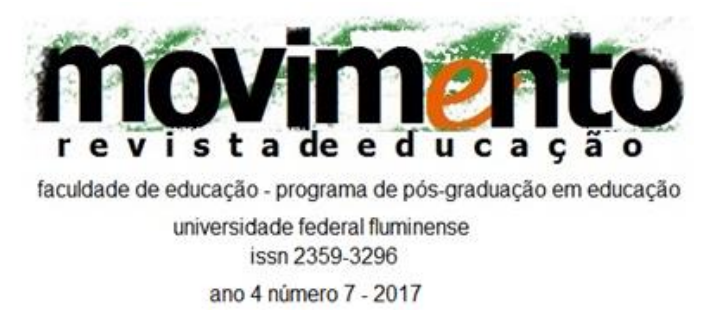

MONTEIRO, Agostinho dos Reis (1998). "(Re)Encontro com Paulo Freire”, Revista de Educação, Vol. III, ํo-1, 123-128.

MORROW, Raymond Allen \& TORRES, Carlos Alberto (1997). Teoria Social e Educação. Uma Crítica das Teorias da Reprodução Social e Cultural. Porto: Afrontamento.

MORROW, Raymond Allen \& TORRES, Carlos Alberto (1998). "Jürgen Habermas, Paulo Freire e a Pedagogia Crítica: novas orientações para a educação comparada", Educação, Sociedade \& Culturas, ํo 10, 123-155.

NOGUEIRA, Adriano \& GERALDI, João W. (orgs.) (1990). Paulo Freire: Trabalho, Comentário, Reflexão. Petrópolis: Vozes.

NÓVOA, António (1998a). "Paulo Freire (1921-1997): A 'Inteireza' de um Pedagogo Utópico", in M.W. Apple \& A. Nóvoa (orgs.), Paulo Freire: Política e Pedagogia. Porto: Porto Editora, 167-191.

O'CADIZ, Maria P., WONG, Pia L. \& TORRES, Carlos A. (1998). Education and Democracy. Paulo Freire, Social Movements, and Educational Reform in São Paulo. Boulder: Westview Press.

OLIVEIRA, Romualdo Portela \& CATANI, Afrânio Mendes (1993). Constituições Estaduais Brasileiras e Educação. São Paulo: Cortez.

PAIVA, Vanilda Pereira (1980). Paulo Freire e o NacionalismoDesenvolvimentista. Rio de Janeiro: Civilização Brasileira.

PARO, Vítor Henrique (1996). Eleição de Diretores. A Escola Pública Experimenta a Democracia. Campinas: Papirus.

PARO, Vítor Henrique (1997). Gestão Democrática da Escola Pública. São Paulo: Ática.

PINTASILGO, Maria de Lourdes (1998). "Prefácio", in M. W. Apple \& A. Nóvoa (orgs.), Paulo Freire: Política e Pedagogia. Porto: Porto Editora, 9-14.

POWER, Sally \& WHITTY, Geoff (1999). "Market Forces and School Cultures", in J. Prosser (ed.), School Culture. Londres: Paul Chapman, 15-29.

PUIGGRÓS, Adriana (1998). "Paulo Freire e os Novos Imaginários Pedagógicos Latino-Americanos", in M.W. Apple \& A. Nóvoa (orgs.), Paulo Freire: Política e Pedagogia. Porto: Porto Editora, 91-112.

ROMÃO, José Eustáquio (2002). Pedagogia Dialógica. São Paulo: Cortez Editora/Instituto Paulo Freire. 


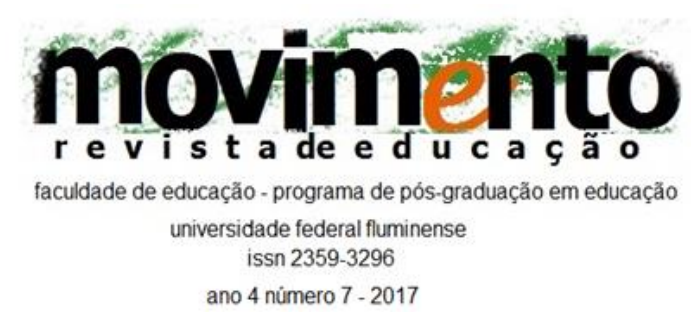

ROSAS, Paulo (2004). Fontes do Pensamento de Paulo Freire. Recife: Ed. Universitária da UFPE.

SANDER, Benno (1995). Gestão da Educação na América Latina. Campinas: Autores Associados.

SAUL, Ana Maria (1998). "A Construção do Currículo na Teoria e Prática de Paulo Freire", in M. W. Apple \& A. Nóvoa (orgs.), Paulo Freire: Política e Pedagogia. Porto: Porto Editora, 151-165.

SAUL, Ana Maria (Org.) (2000). Paulo Freire e a Formação de Educadores. Múltiplos Olhares. São Paulo: Articulação Universidade/Escola.

SCOCOGLIA, Afonso Celso (2001a). A História das Idéias de Paulo Freire e a Atual Crise de Paradigmas. João Pessoa: Ed. Universitária (3ํㅡㄹ. ed.).

SCOCOGLIA, Afonso Celso (2001b). Histórias Inéditas da Educação Popular. Do Sistema Paulo Freire aos IPMs da Ditadura. São Paulo: Cortez/Ed. Universitária/IPF.

SHOR, Ira (1993). "Education is Politics. Paulo Freire's Critical Pedagogy", in P. McLaren \& P. Leonard (eds.), Paulo Freire: A Critical Encounter. Londres: Routledge, 25-35.

SILVA JUNIOR, Celestino A. (1990). A Escola Pública como Local de Trabalho. São Paulo: Cortez e Autores Associados.

SILVA, Tomaz Tadeu da (1996). Identidades Terminais. As Transformações na Política da Pedagogia e na Pedagogia da Política. Petrópolis: Vozes.

SMYTH, John (ed.) (1993). A Socially Critical View of the Self-Managing School. Londres: The Falmer Press.

SOUZA, João Francisco de (1987). Uma Pedagogia da Revolução. A Contribuição do Governo Arraes (1960-1964) à Reinvenção da Educação Brasileira. São Paulo: Cortez Editora/Autores Associados.

SOUZA, João Francisco de (2001). Atualidade de Paulo Freire. Contribuição ao Debate sobre a Educação na Diversidade Cultural. Recife: Edições Bagaço (1르. ed.).

STOER, Stephen R. \& DALE, Roger (1999). "Apropriações Políticas de Paulo Freire: um exemplo da Revolução Portuguesa", Educação, Sociedade \& Culturas, no 11, 67-81. 


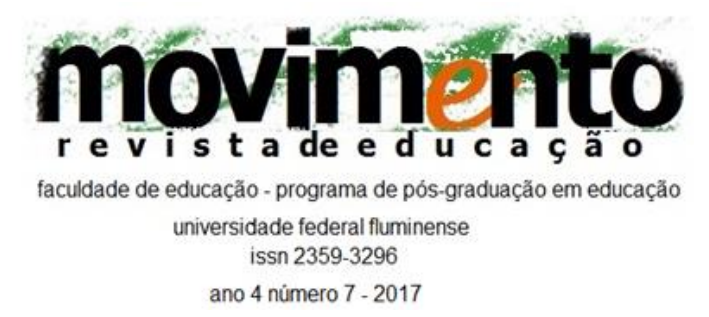

STRECK, Danilo R. (Org.) (1999). Paulo Freire: Ética, Utopia e Educação. Petrópolis: Vozes.

STRECK, Danilo R., REDIN, Euclides, ZITKOSKI, Jaime José (Orgs.) (2009). Dicionário Paulo Freire. Belo Horizonte: Autêntica, $2^{\underline{a}}$ edição.

TORRES, Carlos Alberto (1993). "From the Pedagogy of the Opressed to A Luta Continua. The political pedagogy of Paulo Freire", in P. McLaren \& $\mathrm{P}$. Leonard (eds.), Paulo Freire: A Critical Encounter. Londres: Routledge, 119-145.

TORRES, Carlos Alberto (1994). "Paulo Freire as Secretary of Education in the Municipality of São Paulo", Comparative Education Review, Vol. 38, ㄲo 2, 181-214.

TORRES, Carlos Alberto (1998). "A Pedagogia Política de Paulo Freire", in M. W. Apple \& A. Nóvoa (orgs.), Paulo Freire: Política e Pedagogia. Porto: Porto Editora, pp. 151-165.

TORRES, Carlos Alberto (2005). "Os Mundos Distorcidos de Ivan Illich e Paulo Freire", in António Teodoro \& Carlos Alberto Torres (orgs.), Educação Critica e Utopia. Perspectivas para o Século XXI. Porto: Afrontmento, pp. 83-100.

TORRES, Rosa Maria (Org.) (1987). Educação Popular: Um Encontro com Paulo Freire. São Paulo: Edições Loyola.

VASCONCELOS, Maria Lúcia M. C. \& Brito, Regina Helena P. (2006). Conceitos de Educação em Paulo Freire. São Paulo: Mackenzie.

VASQUEZ, Manuel A. (2000). "Paulo Freire e a Crise da Modernidade", Educação, Sociedade \& Culturas, n.ำ14, pp. 141-158.

WEFFORT, Francisco C. (1967). "Educação e Política (Reflexões sociológicas sobre uma pedagogia da Liberdade)", in Paulo Freire, Educação como Prática da Liberdade. Rio de Janeiro: Paz e Terra, pp. 1-26.

WHITTY, Geoff, POWER, Sally \& HALPIN, David (1998). Devolution and Choice in Education. The School, the State and the Market. Buckingham: Open University Press.

WOODS, Peter \& JEFFREY, Robert (1996). "A New Professional Discourse? Adjusting to Managerialism", in P. Woods (ed.), Contemporary Issues in Teaching and Learning. Londres: Routledge with The Open University, 3856. 


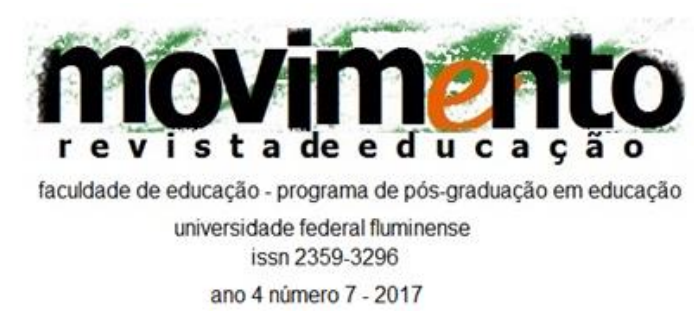

\section{Outras fontes}

DVV (2007). 10 ${ }^{\text {th }}$ Anniversary of Paulo Freire's Death. Adult Education and Development, nำ69,

RADIO NEDERLAND (1998). Paulo Freire. O Andarilho da Utopia. São Paulo: RN/CRIAR (documento CD).

ROCHA, Selma (s.d.). O Modo Petista de Governar a Educação no Brasil. São Paulo: Comissão Nacional de Assuntos Educacionais do Partido dos Trabalhadores (polic.).

SECRETARIA MUNICIPAL DE EDUCAÇÃO (1989). O Movimento de Reorientação Curricular na Secretaria Muncipal de Educação de São Paulo (Documento 2). São Paulo: Município de São Paulo (polic.).

SECRETARIA MUNICIPAL DE EDUCAÇÃO (1991). Seleção e Formação de Operacionais: uma nova experiência na educação municipal. São Paulo: Município de São Paulo.

SECRETARIA MUNICIPAL DE EDUCAÇÃO (1992a). Balanço Geral da SME, Projeção Trienal. São Paulo: Município de São Paulo.

SECRETARIA MUNICIPAL DE EDUCAÇÃO (1992b). Construindo a Educação Pública e Popular. São Paulo: Município de São Paulo.

SECRETARIA MUNICIPAL DE EDUCAÇÃO (1992c). Planejamento. Instrumento de Mobilização Popular. São Paulo: Município de São Paulo.

SECRETARIA MUNICIPAL DE EDUCAÇÃO (1992d). Problematização da Escola: a visão dos educadores, educandos e pais. São Paulo: Município de São Paulo.

SECRETARIA MUNICIPAL DE EDUCAÇÃO (1992e). Regimento em Ação. Caderno 1. São Paulo: Município de São Paulo.

SECRETARIA MUNICIPAL DE EDUCAÇÃO (1992f). Regimento em Ação. Caderno 3. São Paulo: Município de São Paulo.

SECRETARIA MUNICIPAL DE EDUCAÇÃO (1992g). Reorientação Curricular das Escolas Municipais de Educação Infantil. São Paulo: Município de São Paulo.

SECRETARIA MUNICIPAL DE EDUCAÇÃO (1992h). I e // Congressos Municipais de Educação. São Paulo: Município de São Paulo. 


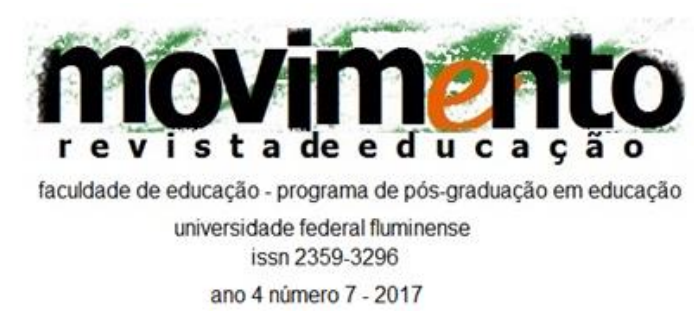

TV PUC (1997). Televisão Comunitária da Pontifícia Universidade Católica de São Paulo. Paulo Freire - "In Memoriam" (video).

CÁTEDRA PAULO FREIRE - ITESO. Paulo Freire Constructor de Sueños (video).

BIBLIOGRAPHY ON PAULO FREIRE. List of titles available in the Documentation Centre of the UNESCO Institute for Education. Compiled by Martina Pfau and Imke Behr, 2004.

PAULO FREIRE. Vídeo Colecção Grandes Educadores, São Paulo.

COLECÇÃO PAULO FREIRE: LEGADO. Vídeo.

COLECÇÃO PAULO FREIRE: EDUCAÇÃO Vídeo.

COLECÇÃO PAULO FREIRE: BIOGRAFIA. Vídeo.

BIBLIOTECA DIGITAL PAULO FREIRE — http://www.paulofreire.uffb.br/

CENTRO PAULO FREIRE - ESTUDOS E PESQUISAS http://www.paulofreire.org.br/

IPF - Instituto Paulo Freire - http://www.paulofreire.org/

SDUM - Serviços de Documentação da Universidade do Minho — http://www.sdum.uminho.pt/

UNICAMP - PAULO FREIRE http://www.lite.fac.unicamp.br/grupos/links/linkpfreire.html

INSTITUTO PAULO FREIRE DE PORTUGAL - http://www.ipfp.pt 


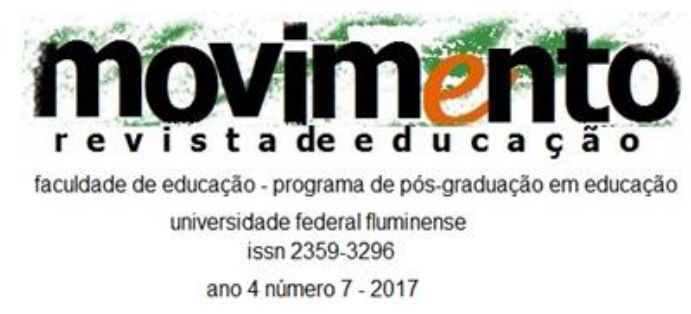

Apêndice II - Informação apresentada ao Conselho Científico do Instituto de Educação da Universidade do Minho (Braga, Portugal, 2014)

\section{PAULO FREIRE}

Ocorreram em 2011, com projeção internacional, as comemorações do nonagésimo aniversário de Paulo Freire (1921-1997), brasileiro nascido em Recife e cidadão do mundo, considerado por vários autores o maior vulto da pedagogia da segunda metade do século XX e um dos mais publicados e estudados académicos da língua portuguesa. Os seus trabalhos estão traduzidos em mais de trinta línguas, foi doutor honoris causa pelas Universidades de Lisboa e do Algarve, a par de mais de três dezenas de Universidades estrangeiras. Continua a ser estudado em cátedras e centros de investigação com o seu nome, designadamente através do Instituto Paulo Freire de Portugal e de outros institutos localizados nos cinco continentes, e por autores como Carlos Alberto Torres, Moacir Gadotti, Henry Giroux, Michael Apple, Peter Jarvis, Peter Mayo, Peter McLaren, António Nóvoa, Remí Klein, Rosa Maria Torres, entre muitos outros. Nos últimos anos foi publicada, no Brasil, a mais extensa e completa biografia de Freire, da autoria de Ana Maria Araújo Freire (2006), a quem foi atribuído o Prémio Jabuti, e nos Estados Unidos foi publicada a Enciclopédia Paulo Freire (Streck, Redin e Zitkosky, 2012). Em 2007, a Associação Alemã de Educação de Adultos (DVV) dedicou-Ihe um número temático da sua revista Adult Education and Development (n 69), à semelhança do que ocorreu com a Revista Lusófona de Educação (nํㅜ 24, 2013).

No Instituto de Educação da Universidade do Minho o autor é estudado, desde 1975, em vários cursos e unidades curriculares, existindo, desde 1999, uma Disciplina de Opção intitulada "Política e Politicidade da Educação: $O$ Pensamento de Paulo Freire". O interesse pela obra de Freire transcende a educação, razão pela qual tem sido estudado em diversas escolas de filosofia, sociologia e economia, sendo ensinado em várias Universidades portuguesas, como é o caso da Faculdade de Economia da Universidade de Coimbra. 


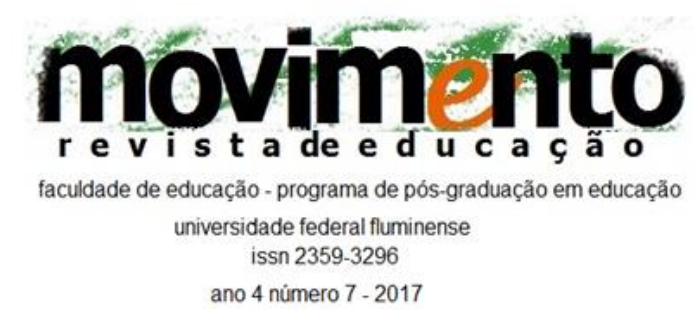

A sua obra continua atual, não apenas os seus livros clássicos e mais conhecidos, como o seu opus magnum "Pedagogia do Oprimido" (Freire, 1975a), e "Educação como Prática da Liberdade" (Freire, 1967), ou ainda "Extensão ou Comunicação?" (Freire, 1975b), mas também os livros que escreveu nas décadas de 1980 e 1990, até à sua morte em 1997. Alguns dos livros escritos depois do regresso de Freire ao Brasil, após o exílio, como "A Educação na Cidade" (Freire, 1991), "Pedagogia da Esperança" (Freire, 1992), "Política e Educação" (1997), "À Sombra desta Mangueira" (2000), ou o muito celebrado "Pedagogia da Autonomia" (Freire, 1996), são trabalhos indispensáveis para conhecer a globalidade do pensamento de Freire e os novos temas educacionais que incorporou na sua obra e pensamento político-educativo. Quase uma dezena dos seus livros mais recentes é ainda menos conhecida por parte de académicos e educadores, contribuindo para a tendência de remeter 0 autor apenas para o contexto político, cultural e educativo dos anos 60 e 70 do século XX. Nesse contexto cronológico, ele foi já considerado um autor clássico, mas isso não dispensa a consideração da fase que foi considerada como de "renascimento pedagógico" de Freire, como Ihe chamou António Nóvoa (1988), isto é, a sua obra educativa como administrador público da cidade de São Paulo, entre 1989 e 1991, como professor universitário (UNICAMP e PUC-SP), como autor que abordou novos temas, através de uma perspetiva original dos problemas do presente, sempre teoricamente ancorada nos seus trabalhos anteriores e nalguns dos conceitos mais criativos que nos deixou.

Referências

NÓVOA, A. (1998). Paulo Freire (1921-1997): A 'Inteireza' de um Pedagogo Utópico. In M. W. Apple \& A. Nóvoa (Orgs.). Paulo Freire: Política e Pedagogia. Porto: Porto Editora, 167-191.

FREIRE, A. M. (2006). Paulo Freire: uma história de vida. São Paulo: Villa das Letras. 


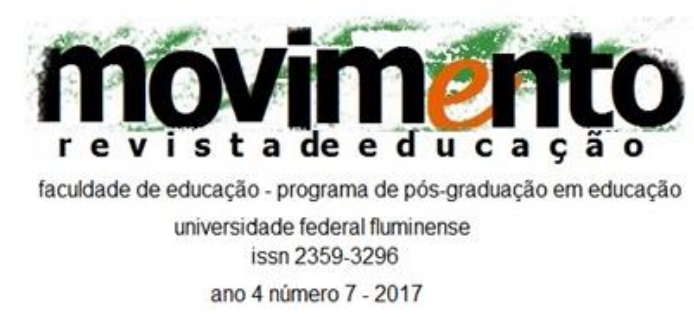

FREIRE, P. (1967). Educação como prática da liberdade. Rio de Janeiro: Paz e Terra.

FREIRE, P. (1975a). Pedagogia do oprimido. Porto: Afrontamento.

FREIRE, P. (1975b). Extensão ou comunicação? Rio de Janeiro: Paz e Terra (1 $1^{a}$ ed. de 1969).

FREIRE, P. (1991). A educação na cidade. São Paulo: Cortez Editora.

FREIRE, P. (1992). Pedagogia da esperança. Um reencontro com a pedagogia do oprimido. São Paulo: Paz e Terra.

FREIRE, P. (1996). Pedagogia da autonomia. Saberes necessários à prática educativa. São Paulo: Paz e Terra.

FREIRE, P. (1997). Política e educação. São Paulo: Cortez (3ª ed.).

FREIRE, P. (2000). À sombra desta mangueira. São Paulo: Olho d'Água ( $3^{\mathrm{a}}$ ed.). STRECK, D., REDIN, S., ZITKOSKI, J. (Eds.) (2012). Paulo Freire Encyclopedia. Lanham, Boulder, New York, Toronto, Plymouth: Rowman \& Littlefield.

[Nota redigida por Licínio C. Lima em setembro de 2014 como informação prévia à tomada de decisão pelo Conselho Científico do Instituto de Educação da Universidade do Minho no sentido de atribuir à sua Sala de Reuniões a designação de "Sala Paulo Freire".] 


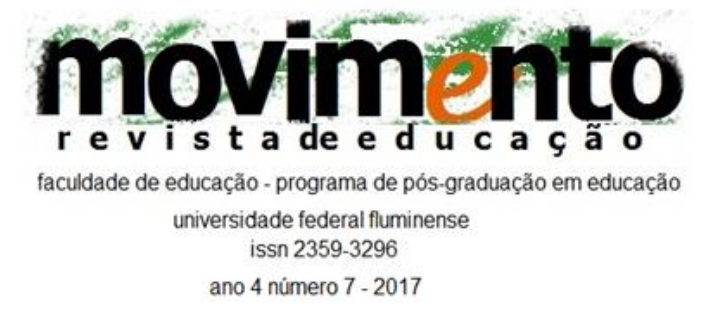

\section{Apêndice III - Convite para a inauguração da Sala Paulo Freire}

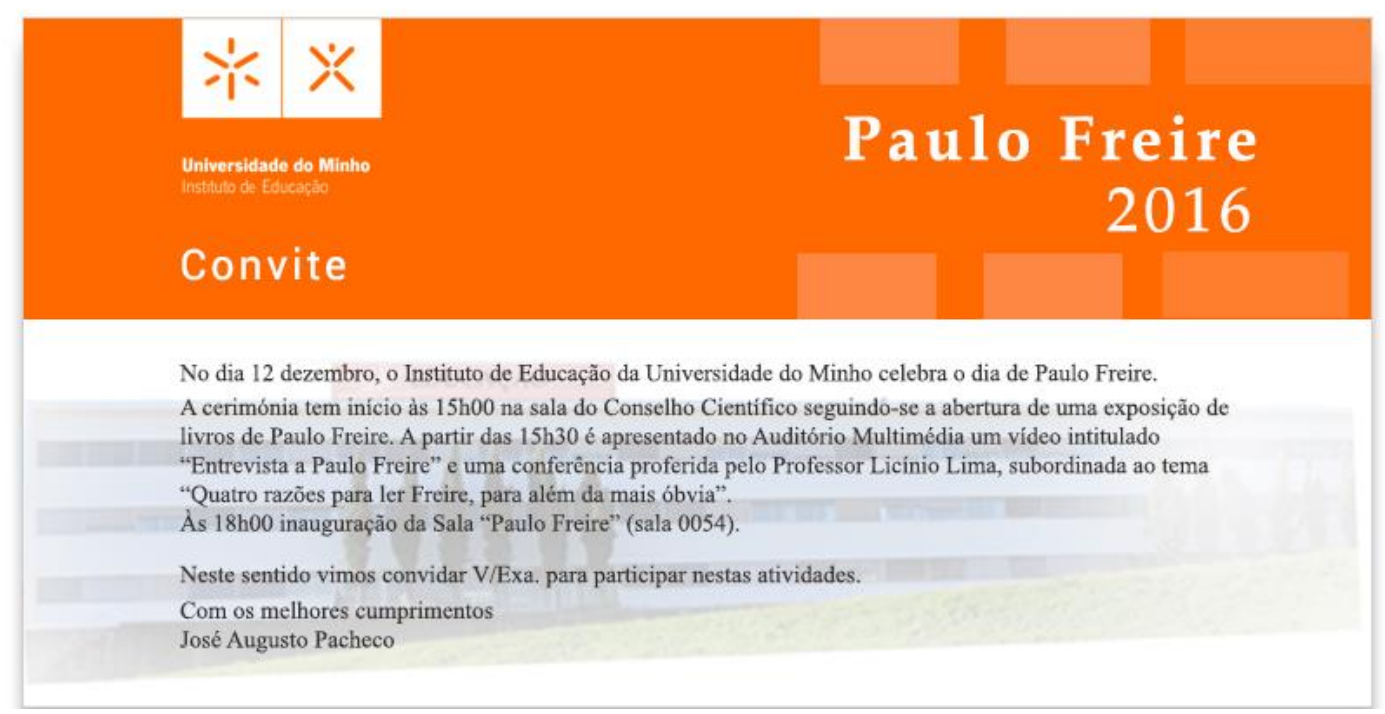

Recebido em: 10.10 .2017

Aceito em: 10.10.2017 